\title{
A Comparative Analysis of the Upcoming Beijing-Tianjin-Hebei Region
}

\author{
Tang, Shaoqing (Corresponding author) \\ Associate Dean, Professor \\ Business School of Beijing Union University \\ E-mail: shaoqing.tang@buu.edu.cn \\ Jiang, Pengfei \\ Associate Professor \\ Business School of Beijing Union University \\ E-mail: pengfei.jiang@buu.edu.cn \\ Guo, Xiuli \\ Lecturer \\ Business School of Beijing Union University \\ E-mail: xiuli.guo@buu.edu.cn
}

Received: February 9, 2016

doi:10.5296/jad.v2i1.9005
Accepted: March 2, 2016 Published: April 13, 2016

URL: http://dx.doi.org/10.5296/jad.v2i1.9005

\begin{abstract}
The integrated development of Beijing-Tianjin-Hebei region has become one of the national economic development strategies in China. To understand this strategy, this paper studies the regional and industrial characteristics of the upcoming Beijing-Tianjin-Hebei (BTH) region, compares the BTH region with its existing counterparts in the Yangtze River Delta (YRD) region and the Pearl River Delta (PRD) region in China, and also compares this upcoming economic circle with other five global metropolis circles. From the theoretical perspective of integrated development, this paper analyzes the possible sustainable development path for
\end{abstract}


this new economic circle.

Keywords: China, Regional Integration, Urban Economic Circle, Comparative Study

\section{Introduction}

Urban Economic Circle (UEC) is a concept in modern economic development, pioneered by the French geographer Jean Gottmann (1957). A UEC is an industrial combination with inner links, which is based on natural resources, economic and technological conditions, and government's macro-management. It covers a large area, including one or a few developed cities as core cities and a certain number of nearby towns that have inherent economic relations. A UEC can promote the regional economic maximization. The construction of Japan's postwar economic circle followed this model, which has been realized by separating the administrative divisions, letting central cities play the leading roles, and developing the horizontal economic ties between cities and enterprises. A UEC usually has raw material supplies areas, energy generation areas, production areas and agricultural bases, so as to form a comprehensive industrial circle.

Characteristics of a UEC can be summarized as follows:

(1) Layered. A UEC uses the core city as the center and develops an outer-layered structure. According to their impacts and different functions, the surrounding regions are often divided into several layers: the core urban area, urban area (including core built-up area and suburban areas rings), metropolis circle and large metropolitan region.

(2) Hierarchical. According to its economic impact, UECs can be divided into different levels, such as international, national, regional, etc. A high level UEC contains low-level city economic circles. For example, the Shanghai Urban Economic Circle contains Nanjing, Suzhou, Wuxi, Changzhou economic circles.

(3) Clustering. A UEC is intensive not only in population, natural resources and other basic factors of production, but also the center of modern industries. It has strong regional competitiveness and enormous economic outputs.

(4) Integrated. A UEC gives full play to the basic role of market in resource allocation, breaks regional and rural-urban divisions, promotes the rational distribution of regional industry and the free flow of factors, and achieves comparative and competitive advantages between cities and regions. Relying on close-knit urban networks (inter-city transportation network, communication network, commodity distribution networks, financial networks, etc.), a UEC builds a development platform and forms a functional integrated economic region.

(5) Well planned. Government needs to carry out long-term strategic planning. Moreover, planning is achieved through coordination among different local governments. The coordination among governments can eliminate conflicts of policies and systems in different administrative areas, break administrative barriers down, reduce transaction costs and administrative costs, and unify the regional markets to realize the free flow of production factors, goods and personnel. 


\section{I Macrothink}

At the symposium on the collaborative development of Beijing-Tianjin-Hebei region (see Figure 1) held on February 26, 2014, Xi Jinping, the President of the People's Republic of China, made it clear that "achieving collaborative development of Beijing-Tianjin-Hebei is a major national strategy. We need to find out a scientific and sustainable path of collaborative development." While such a new economic strategy provides new opportunities for domestic and foreign investors and entrepreneurs, it is necessary to understand the background of the coming opportunities and analyze the possible approaches to achieve a sustainable development in Beijing-Tianjin-Hebei (BTH) region.

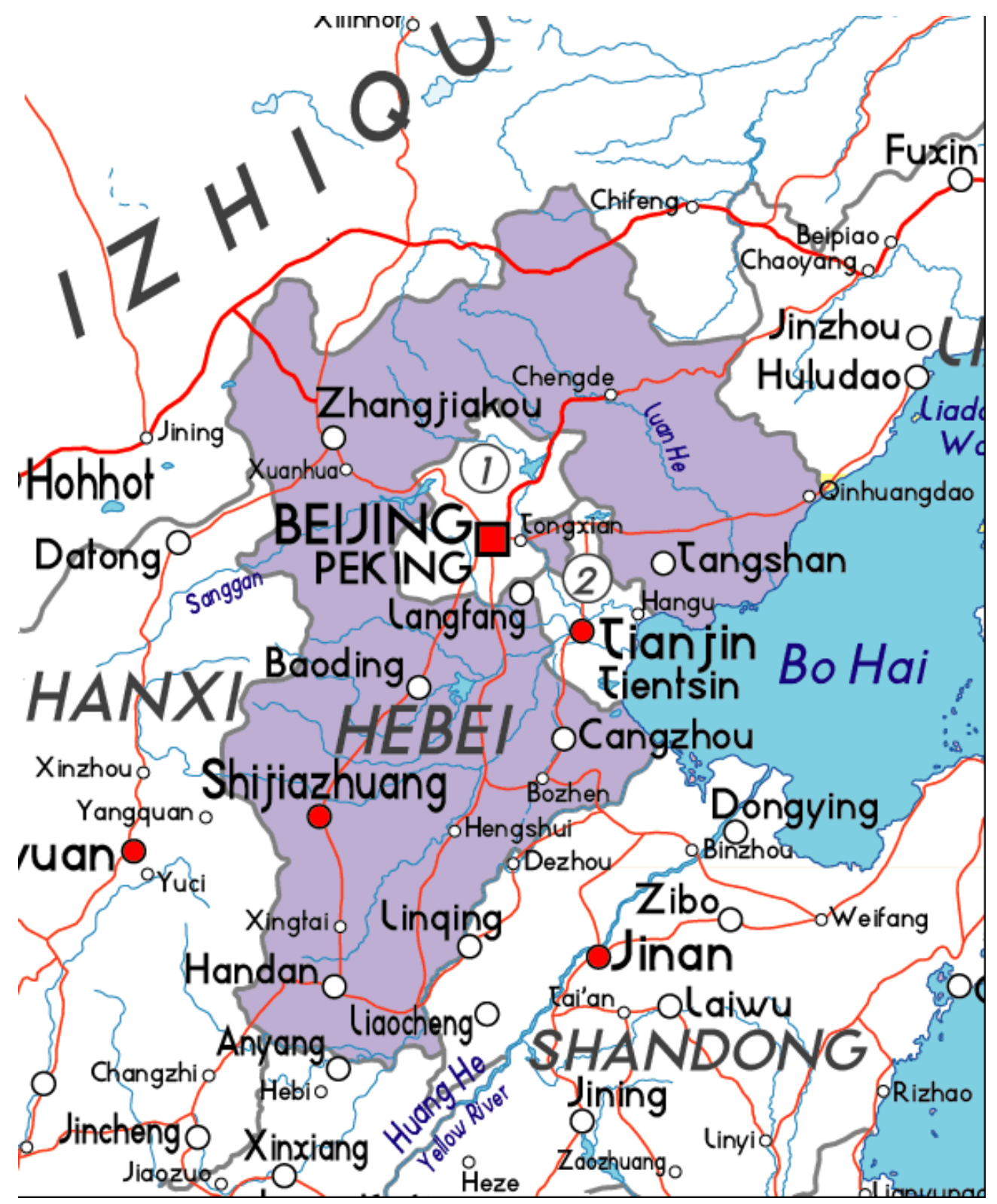

Figure 1. The Region of the Beijing-Tianjin-Hebei 


\section{The BTH UEC's Characteristics}

\subsection{BTH's Regional Characteristics}

Beijing is gradually withdrawing from the "economic center" and accelerating the development of the tertiary industries. Tianjin is restoring its role of economic center in north China and developing the Binhai New Area (a new costal industrial area). Utilizing the advantage of raw material supplies and relying on Caofeidian (a land reclamation-converted economic development zone in the Bohai Bay), Hebei province is vigorously developing new manufacturing industries. The BTH UEC has Beijing and Tianjin as the dual centers, and includes Shijiazhuang, Baoding, Qinhuangdao, Langfang, Cangzhou, Chengde, Zhangjiakou and Tangshan, eight cities in Hebei Province. It covers an area of 183,704 square kilometers, accounting for $1.9 \%$ of China's total area. It's population is $76,051,300$, accounting for $5.79 \%$ of the total China's population.

\subsection{BTH's Industrial Characteristics}

There is a relatively complete industrial system in the BTH metropolis circle, which includes high-end industries like information media, scientific and technological innovation, financial services, culture and sports, modern manufacturing industries like telecommunication equipment, computers and other electronic equipment manufacturing, automobile manufacturing, pharmaceutical manufacturing, and basic industries like iron ore, coal, oil, ferrous metallurgy, petroleum processing, integrated chemical and agricultural production. Beijing has formed a tertiary-secondary-primary industrial structure, which is at an advanced stage of industrialization. Tianjin has formed a secondary-tertiary-primary industrial structure, which is at the intermediate stage of industrialization. However, the industrial structures of the eight cities in Hebei province are quite different, which are overall in the early stage of industrialization. Therefore, the BTH UEC has industrial gradients and needs to upgrade its industrial structure.

\section{Comparison with Existing UECs in China}

From the regional perspective, Beijing-Tianjin-Hebei region is different from the Yangtze River Delta (YRD) region and the Pearl River Delta (PRD) region. Driven by the pilot development in Shanghai and Shenzhen respectively, the YRD region and the PRD region have developed rapidly, and even promoted China's economy to leap forward. Using the two existing Chinese UECs as the benchmark, we can make a comparative analysis among BTH, YRD and PRD (see Table 1).

Table 1 shows that the BTH's GDP per capita lags behind both the YRD and the PRD regions. From the view of export-oriented economy, the BTH region falls behind both the YRD and the PRD regions in the total import and export volume and the actual utilization of foreign capital. From the view of marketization reform process, the BTH's urbanization rate is lower than the average level of the YRD and the PRD regions. 
Table 1. Comparison with two other economic circles in China

\begin{tabular}{|c|c|c|c|}
\hline Items & The BTH region & The YRD region & The PRD region \\
\hline $\begin{array}{l}\text { Area (accounting for } \\
\text { proportion in China) }\end{array}$ & $1.9 \%$ & $1.2 \%$ & $0.6 \%$ \\
\hline $\begin{array}{l}\text { Population (accounting for } \\
\text { proportion in China) }\end{array}$ & $6.4 \%$ & $7.6 \%$ & $4.2 \%$ \\
\hline $\begin{array}{l}\text { GDP (accounting for } \\
\text { proportion in China) }\end{array}$ & $10.0 \%$ & $17.4 \%$ & $9.2 \%$ \\
\hline $\begin{array}{l}\text { Total Volume of Foreign } \\
\text { Trade (accounting for } \\
\text { proportion in China) }\end{array}$ & $14.3 \%$ & $27.7 \%$ & $24.4 \%$ \\
\hline $\begin{array}{l}\text { Actual Utilization of } \\
\text { Foreign Capital (accounting } \\
\text { for proportion in China) }\end{array}$ & $19.0 \%$ & $47.9 \%$ & $19.9 \%$ \\
\hline $\begin{array}{l}\text { The Standard of Population } \\
\text { Urbanization }\end{array}$ & $56.2 \%$ & $65.0 \%$ & $66.0 \%$ \\
\hline Core cities & Beijing, Tianjin & $\begin{array}{l}\text { Shanghai, Nanjing, } \\
\text { Hangzhou }\end{array}$ & Guangzhou, Shenzhen \\
\hline Cities included & $\begin{array}{l}2 \text { municipalities, } 1 \\
\text { provincial city, } 11 \\
\text { prefecture-level cities }\end{array}$ & $\begin{array}{l}1 \text { municipality, } 2 \\
\text { sub-provincial cities, } 13 \\
\text { prefecture-level cities }\end{array}$ & $\begin{array}{l}2 \text { sub-provincial cities, } 12 \\
\text { prefecture-level cities }\end{array}$ \\
\hline Center City's Function & Political center & $\begin{array}{l}\text { Modern industrial and } \\
\text { economic center }\end{array}$ & $\begin{array}{l}\text { Foreign trade and economic } \\
\text { center }\end{array}$ \\
\hline Structure & Government body & $\begin{array}{l}\text { Dominated by Government; } \\
\text { market mechanism also } \\
\text { included }\end{array}$ & $\begin{array}{l}\text { Interaction between } \\
\text { Government and market }\end{array}$ \\
\hline Competitiveness & $\begin{array}{l}\text { High aggregation } \\
\text { competitiveness }\end{array}$ & $\begin{array}{l}\text { High regional } \\
\text { competitiveness }\end{array}$ & $\begin{array}{l}\text { High system } \\
\text { competitiveness }\end{array}$ \\
\hline Dynamic Mechanism & State-owned led & Private capital led & Foreign capital driven \\
\hline Development engine & Domestic demand-driven & Investment-driven & Export-driven \\
\hline High-tech industry & $\begin{array}{l}\mathrm{R} \& \mathrm{D} \text { institutions-related } \\
\text { industries and headquarters } \\
\text { economy }\end{array}$ & $\begin{array}{l}\text { Microelectronics, optical } \\
\text { communications, } \\
\text { bio-engineering }\end{array}$ & $\begin{array}{l}\text { Electronic information, } \\
\text { electrical machinery, } \\
\text { petrochemicals }\end{array}$ \\
\hline Characteristics & State-owned model & $\begin{array}{l}\text { Comprador economic model, } \\
\text { Wenzhou model, South of } \\
\text { Jiangsu model }\end{array}$ & $\begin{array}{l}\text { South China sea model, } \\
\text { Shunde model, Shenzhen } \\
\text { model, Dongguan model }\end{array}$ \\
\hline
\end{tabular}

Source: Data calculated according to the China Statistical Yearbook 2013 \& Provincial Statistical Yearbook 2013.

\section{Comparison with Global UECs}

In the 20th century, five famous UECs in the world have been formed, which are New York, the Great Lakes in North America, Tokyo, Paris, and London. They play leading roles in the development of national and world economies and have a strong ability of radiation.

Using the top five metropolis circles in the world as the benchmark, the BTH UEC should find its own advantages and disadvantages and pursue its own appropriate development model or development strategy (see Table 2). 
Table 2. Comparison with world's top five metropolis circles

\begin{tabular}{|c|c|c|c|c|c|c|}
\hline Items & $\begin{array}{l}\text { New York } \\
\text { UEC }\end{array}$ & $\begin{array}{l}\text { Great } \\
\text { UEC }\end{array}$ & Tokyo UEC & Paris UEC & London UEC & $\begin{array}{l}\text { BTH } \\
\text { metropolis } \\
\text { circle }\end{array}$ \\
\hline Scope & $\begin{array}{l}\text { Boston, New } \\
\text { York, } \\
\text { Philadelphia, } \\
\text { Baltimore and } \\
\text { Washington, } 40 \\
\text { small } \\
\text { medium-sized } \\
\text { cities }\end{array}$ & $\begin{array}{l}\text { Chicago, } \\
\text { Detroit, } \\
\text { Cleveland, } \\
\text { Pittsburgh, } \\
\text { Toronto and } \\
\text { Montreal }\end{array}$ & $\begin{array}{l}\text { Tokyo, Saitama, } \\
\text { Chiba, Kanagawa } \\
\text { Prefecture }\end{array}$ & $\begin{array}{l}\text { Paris, } \\
\text { Amsterdam, } \\
\text { Rotterdam, } \\
\text { Antwerp, } \\
\text { Brussels and } \\
\text { Cologne }\end{array}$ & $\begin{array}{l}\text { London, } \\
\text { Birmingham, } \\
\text { Sheffield, } \\
\text { Manchester, } \\
\text { Liverpool, } \\
\text { etc. }\end{array}$ & $\begin{array}{l}\text { Beijing, Tianjin, } \\
\text { Shijiazhuang } \\
\text { and other cities. }\end{array}$ \\
\hline Area & $\begin{array}{l}138,000 \text { square } \\
\text { kilometers }\end{array}$ & $\begin{array}{l}94,200 \text { square } \\
\text { kilometers }\end{array}$ & $\begin{array}{l}13,400 \text { square } \\
\text { kilometers }\end{array}$ & $\begin{array}{l}145,000 \text { square } \\
\text { kilometers }\end{array}$ & $\begin{array}{l}45,000 \text { square } \\
\text { kilometers }\end{array}$ & $\begin{array}{l}183,700 \text { square } \\
\text { kilometers }\end{array}$ \\
\hline Population & 65 million & 59million & 34million & 46million & 36.5million & 90million \\
\hline $\begin{array}{l}\text { Planning and } \\
\text { construction }\end{array}$ & $\begin{array}{l}\text { four stages: } \\
\text { isolated city in } \\
1870 \text {, regional } \\
\text { city between } \\
1870 \text { and } 1920, \\
\text { early state of } \\
\text { metropolis } \\
\text { circle between } \\
1920 \text { and } 1950 \text {, } \\
\text { the formation of } \\
\text { metropolis } \\
\text { circle in } 1950\end{array}$ & $\begin{array}{l}\text { first adjustment } \\
\text { to the suburbs in } \\
1921 \text {, the second } \\
\text { time to plan to } \\
\text { build a number } \\
\text { of urban centers } \\
\text { in } 1968, \text { the } \\
\text { planning of } \\
\text { Atlantic coast } \\
\text { city zone in the } \\
\text { Northeastern } \\
\text { America in } 1996\end{array}$ & $\begin{array}{l}\text { "Metropolitan } \\
\text { reorganization } \\
\text { plan" in 1956, } \\
\text { Greater Tokyo } \\
\text { Metropolitan } \\
\text { construction plan } \\
\text { in 1968, the } \\
\text { establishment of } \\
\text { regional } \\
\text { multi-center } \\
\text { complex city in } \\
\text { 1976, a } \\
\text { multi-polar, and } \\
\text { multi-circle of the } \\
\text { city structure in } \\
\text { 1985. }\end{array}$ & $\begin{array}{l}\text { based on the } \\
\text { need for regional } \\
\text { development, set } \\
\text { up the Paris } \\
\text { region in 1932, } \\
\text { "the Paris area } \\
\text { land } \\
\text { development } \\
\text { plan" in 1956, } \\
\text { "the Paris area } \\
\text { remediation plan } \\
\text { management } \\
\text { framework" in } \\
\text { 1960, "the Paris } \\
\text { Region Master } \\
\text { Plan' in } 1994\end{array}$ & $\begin{array}{l}\text { the early } \\
\text { planning in } \\
1930 \text { and the } \\
\text { modern } \\
\text { planning in } \\
1992\end{array}$ & $\begin{array}{l}\text { China National } \\
\text { Development } \\
\text { and Reform } \\
\text { Commission } \\
\text { started the } \\
\text { preparation of } \\
\text { BTH Regional } \\
\text { Planning in } \\
\text { November } 2004\end{array}$ \\
\hline $\begin{array}{l}\text { Layer } \\
\text { structure }\end{array}$ & $\begin{array}{l}\text { Spire is New } \\
\text { York, the } \\
\text { second layer is } \\
\text { Boston, } \\
\text { Philadelphia, } \\
\text { Baltimore, } \\
\text { Washington } 4 \\
\text { big cities, and } \\
\text { then the next is } \\
\text { around more } \\
\text { than } 40 \text { small } \\
\text { medium-sized } \\
\text { cities around the } \\
\text { five core cities. }\end{array}$ & $\begin{array}{l}\text { More than } 20 \\
\text { large cities with } \\
\text { population of } \\
\text { one million }\end{array}$ & $\begin{array}{l}\text { Central } \\
\text { management city, } \\
\text { manufacturing } \\
\text { city, city of } \\
\text { residence, city of } \\
\text { production and } \\
\text { life, academy city, } \\
\text { tourist city. }\end{array}$ & $\begin{array}{l}\text { Construction } \\
\text { space, } \\
\text { agricultural } \\
\text { space and natural } \\
\text { space }\end{array}$ & $\begin{array}{l}\text { Inner London, } \\
\text { Greater } \\
\text { London, } \\
\text { standard } \\
\text { metropolitan } \\
\text { service area, } \\
\text { London } \\
\text { Metropolitan } \\
\text { area }\end{array}$ & $\begin{array}{l}\text { Including two } \\
\text { municipalities } \\
\text { Beijing and } \\
\text { Tianjin, and } 8 \\
\text { Provincial level } \\
\text { cities: } \\
\text { Tangshan, } \\
\text { Shijiazhuang, } \\
\text { Qinhuangdao, } \\
\text { Langfang, } \\
\text { Baoding, } \\
\text { Cangzhou, } \\
\text { Zhangjiakou, } \\
\text { Chengde }\end{array}$ \\
\hline $\begin{array}{l}\text { Industrial } \\
\text { structure }\end{array}$ & $\begin{array}{l}\text { Commerce, } \\
\text { research and } \\
\text { development } \\
\text { institutions, the } \\
\text { political center, } \\
\text { harbor }\end{array}$ & $\begin{array}{l}\text { Environmental } \\
\text { protection }\end{array}$ & $\begin{array}{l}\text { Manufacturing, } \\
\text { financial services }\end{array}$ & $\begin{array}{l}\text { Luxury goods } \\
\text { manufacturing } \\
\text { and tertiary } \\
\text { industry }\end{array}$ & $\begin{array}{l}\text { The financial } \\
\text { industry and } \\
\text { the cultural } \\
\text { and creative } \\
\text { industries }\end{array}$ & $\begin{array}{l}\text { High-tech } \\
\text { industries, } \\
\text { modern service } \\
\text { industry }\end{array}$ \\
\hline Characteristics & $\begin{array}{l}\text { Most complete } \\
\text { and most } \\
\text { orderly } \\
\text { industrial } \\
\text { divisions }\end{array}$ & $\begin{array}{l}\text { Strong industrial } \\
\text { upgrading and } \\
\text { sustainable } \\
\text { development }\end{array}$ & $\begin{array}{l}\text { Integration of } \\
\text { transport and } \\
\text { ports }\end{array}$ & $\begin{array}{l}\text { High quality of } \\
\text { urban life, } \\
\text { balanced } \\
\text { development }\end{array}$ & $\begin{array}{l}\text { Creative } \\
\text { industries and } \\
\text { regional } \\
\text { economy }\end{array}$ & $\begin{array}{l}\text { Interaction } \\
\text { between the } \\
\text { two cities and } \\
\text { one province }\end{array}$ \\
\hline
\end{tabular}


The Table 2 shows:

(1) The metropolis circles often present in a ring structure or a layering structure.

(2) The transportation capability of metropolis circles is very strong.

(3) The urbanization degree is high and the tertiary industries are well developed.

\section{Theory Analysis of the Integration of BTH Region}

Rostow's theory of regional economic development (Rostow, 1960; Parr, 2001) believes that when the regional economy develops, the regional economic spatial structure should change accordingly. When the economic development comes to an advanced stage, the economic space will be relatively balanced and the regional urbanization will be well developed (Mishra, 2010). The regions become functionally interdependent urban systems. Urban economic circle is an organizational integration to make the regions connected and regional economy developed in a relatively balanced way.

The integrated development of BTH region can be analyzed from the following four dimensions:

(1) There should be a consensus on collaborative development between the central government and local governments. Collaborative development refers to the local government's cooperation behavior between different regions and between different zones within the region in order to achieve a win-win situation (Lukermann, 1997). In the process of regional cooperation, the primary role of government is to promote the rational flow of resources and correct market misbehaviors in order to realize the regional coordinated development. Beijing, Tianjin and Hebei have a special historical root and their economic developments have the characteristics of echelon, complementarity and symbiosis, which provide a good basis for the regional cooperation.

(2) Because of different industrial structures, there is an echelon development in the region. Echelon refers to the stage characteristics between different regions due to the existence of economic and social development gap (Mazhar, 2015). Echelon triggers the endogenous motivation of the regional cooperation. According to the gradient development theory, each region can achieve balanced regional development through the rational labor assignment and technology transfer (Mazhar, 2015; Mazarr, 1999). The development in the BTH region has the obvious characteristics of echelon. According to the World Bank income group standards in different countries, Beijing and Tianjin have reached the level of developed countries, but Hebei Province has only reached the middle level. In 2012, the proportion of tertiary industry in Beijing reached 76.5\%, but Tianjin's and Hebei Province's were 47\% and 35.3\% respectively. There is a big gap of economic and social development in the region. Echelon provides a theoretical premise for the cooperation in the BTH region. By promoting the orderly transfer of industries, the region can achieve the mutual benefits and win-win situation.

(3) Because of different natural resources, there is complementary development in the region. Complementarity reflects the possibility that various regions benefit from the transaction 
based on each party's comparative advantage (Plummer and Taylor, 2001). According to the theory of comparative advantage, each party in the region should focus on the development of industries with its own comparative advantage and then benefits from the regional trade (Phillips, 2011). There are different factor endowments in Beijing, Tianjin and Hebei Province. Beijing has rich resources in education, culture, science and technology. Tianjin has shipping, logistics and manufacturing advantages. Hebei Province has labor, land and other cost advantages. The three parties should complement each other in the development process so as to amplify local advantages. Complementarity also creates the conditions for leveraging the development of all regions. A certain stage during the development of individual regions tends to be constrained by the local resources. If there is complementarity between regions, it can effectively relieve the constraints and provide continuous power for the regional development. Beijing and Tianjin have a wealth of scientific and technological, cultural and educational resources, but are also faced with the excessive concentration of population, traffic congestion, air pollution and other urban diseases. Hebei Province has a broad industrial load space; however, due to the lack of development resources, Hebei faces the pressure of industrial transformation and upgrading. Regional cooperation can achieve regional advantage and promote regional sustainable development.

(4) Because of integration, there is a joint development in the region. Symbiosis refers to the interdependence of the different parties within the region. The reason for the existence of symbiosis is the externalities of regional public goods (Underhill, 2000). We can't solve many problems such as air pollution, water pollution and food safety within a single region because public goods, including air, water and food, all have cross-border flow characteristics. Only through regional cooperation and within the integrated framework, can systematic solutions be put forward. Currently, Beijing, Tianjin and Hebei province are facing serious air pollution, water shortages and other common problems. It is urgent to strengthen the regional cooperation and promote the orderly development of the regional integration.

\section{Conclusion}

According to the development track of the world's top five UECs, their formations and evolutions all have experienced five stages: central city growing, core city expanding, integration of urban and suburban development, the cooperation and development of multi-core metropolitan regions, and the coordinated development of urban agglomeration. Therefore, currently, the BTH metropolis circle is in the stage of "cooperation and development of multi-core metropolitan regions". The top-level design, market mechanisms, and collaborative development can promote the integration of sustainable development in the BTH region (Tang, 2014).

The essence of regional economic integration is to break down the boundaries of administrative divisions, to unify planning and layout, to organize specialized production and cooperation of division of labor, to establish a unified market, where there are complementary advantages and joint collaboration, and to form an interest community of destiny. In the development process of BTH UEC, the integrated development should be the central task. In a market economy, a region should adhere to the top-level design, give full play to the 
characteristics of same direction of economic development and complementary industrial structure, promote the free flow of factors of production, accelerate the industry integration and restructuring, and implement the regional economic integration and cooperation, so as to participate in the competition as a whole.

Fostering and developing two growth poles are necessary for the BTH UEC's success. The main point of growth pole theory is that regional economic development relies mainly on a few areas with better conditions and a few industries, which should be fostered into economic growth pole, through Polarization and diffusion effect of growth pole, to influence and drive the surrounding region and the development of other industries (Hite, 2004). Beijing and Tianjin should be taken as the twin growth poles of the BTH metropolis circle. Through the development of headquarters economy, giving full play to the efficiency of the economy after the Olympic Games, and accelerating the development of the tertiary industry, Beijing will be developed into China's "Silicon Valley" and a "cultural industry center." Through the integration, function positioning, and function allocation of Tianjin and several ports nearby in Hebei province, the Tianjin Port will be developed into northern China's "Malacca". With the help of policies and opportunities that China central government allows Tianjin to be financial reform pilot, Tianjin will be developed into the freight station where the Chinese capital can go overseas and foreign capital comes into China, becoming China's "Wall Street."

The BTH UEC may apply three-level development strategies. First, enhance the competitiveness of core cities and give full play to their diffusion effects. The central city will first produce agglomeration effects, and agglomeration effects bring diffusion effects, then diffusion effects further enhance clustering capabilities. The first layer of development is to enhance the agglomeration efficiency of the core cities. On the one hand, the agglomeration can strengthen the support in policy, resources, information and talents, and promote the development of competitive industries. On the other hand, the agglomeration can avoid metropolitan problems, promote residential suburbanization, reasonably control the floating population, and strengthen energy conservation efforts. Secondly, take advantage of urban population level effects and build a "pyramid" type urban system. The second layer of development is to give play to the diffusion effects of the core cities. Quality resources in the core city will drive the development of other cities in the metropolis circle. Basic characteristic of the metropolis circle is the distribution of cities and towns is hierarchical; the rational urban scale system should be a "pyramid" type and from the spire to the base are the central cities, sub-central cities, medium sized cities and small cities. Urban hierarchy system is an important condition for achieving the allocation of resources in the metropolis circles and functional complementation and cooperation between cities. Now the BTH metropolis circle is facing the problems of a lack of sub-central cities, fewer medium-sized cities and too many small cities. The third layer of development is to give play to the overall diffusion effect of metropolis circle, put forward the concept of "Pan BTH Metropolis circle" and promote the whole region's development. 


\section{References}

Gottmann, J. (1957). Megalopolis or the urbanization of the northeastern seaboard. Economic Geography, 33(3), 189-200. http://dx.doi.org/10.2307/142307

Hite, A. B. (2004). Natural resource growth poles and frontier urbanization in Latin America. Studies in Comparative International Development, 39(3), 50-75. http://dx.doi.org/10.1007/BF02686282

Lukermann, B. L. (1997). Review on "Principles of Sustainable Development". Journal of the American Planning Association, 63(4), 513-515.

Mazarr, M. J. (1999). What's next for Mexico: Potential surprises from a U.S. neighbor. Futurist, 33(8), 20-26.

Mazhar, M. S. (2015). Issues of Good Governance in South Asia. South Asian Studies, 30 (2), 125-160.

Mishra, P. (2010). Economics of Development and Planning-Theory and Practice (pp. 127-136). Himalaya Publishing House.

Parr, J. B. (2001). On the regional dimensions of Rostow's theory of growth. Review of Urban \& Regional Development Studies, $13(1), \quad 2-19$. http://dx.doi.org/10.1111/1467-940X.00028

Phillips, D. (2011), The Individual and the Social: A comparative study of quality of life, social quality and human development approaches. International Journal of Social Quality, 1(1), 71-89. http://dx.doi.org/10.3167/IJSQ.2011010107

Plummer, P., \& Taylor, M. (2001), Theories of local economic growth (part 1): concepts, models, and measurement. Environment and Planning A., 33, 219-236. http://dx.doi.org/10.1068/a339a

Rostow, W. W. (1960). The Five Stages of Growth-A Summary, The Stages of Economic Growth: A Non-Communist Manifesto (pp. 4-16). Cambridge: Cambridge University Press.

Tang, S. Q. (2014). Continuing to promote the coordinated development of Beijing-Tianjin-Hebei region (J). Qianjin, June 2014 (pp. 55-57).

Underhill, G. R. D. (2000). State, market, and global political economy: genealogy of an $\begin{array}{llll}\text { (inter-?) discipline. International } & \text { Affairs, }\end{array}$ http://dx.doi.org/10.1111/1468-2346.00166

\section{Copyright Disclaimer}

Copyright reserved by the authors.

This article is an open-access article distributed under the terms and conditions of the Creative Commons Attribution license (http://creativecommons.org/licenses/by/3.0/). 